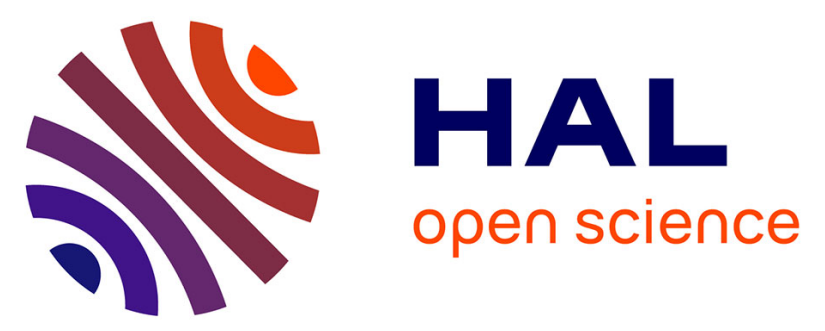

\title{
Survival and growth of Nothofagus pumilio seedlings under several microenvironments after variable retention harvesting in southern Patagonian forests
}

Guillermo J. Martínez Pastur, Rosina Soler Esteban, Juan M. Cellini, María V. Lencinas, Pablo L. Peri, Mark G. Neyland

\section{To cite this version:}

Guillermo J. Martínez Pastur, Rosina Soler Esteban, Juan M. Cellini, María V. Lencinas, Pablo L. Peri, et al.. Survival and growth of Nothofagus pumilio seedlings under several microenvironments after variable retention harvesting in southern Patagonian forests. Annals of Forest Science, 2014, 71 (3), pp.349 - 362. 10.1007/s13595-013-0343-3 . hal-01101533

\section{HAL Id: hal-01101533 \\ https://hal.science/hal-01101533}

Submitted on 8 Jan 2015

HAL is a multi-disciplinary open access archive for the deposit and dissemination of scientific research documents, whether they are published or not. The documents may come from teaching and research institutions in France or abroad, or from public or private research centers.
L'archive ouverte pluridisciplinaire $\mathbf{H A L}$, est destinée au dépôt et à la diffusion de documents scientifiques de niveau recherche, publiés ou non, émanant des établissements d'enseignement et de recherche français ou étrangers, des laboratoires publics ou privés. 


\title{
Survival and growth of Nothofagus pumilio seedlings under several microenvironments after variable retention harvesting in southern Patagonian forests
}

\author{
Guillermo J. Martínez Pastur • Rosina Soler Esteban • \\ Juan M. Cellini • María V. Lencinas • Pablo L. Peri • \\ Mark G. Neyland
}

Received: 30 July 2013 / Accepted: 30 October 2013 /Published online: 22 November 2013

(C) INRA and Springer-Verlag France 2013

\begin{abstract}
- Context Variable retention prescriptions for Nothofagus pumilio forests provide for biodiversity conservation and natural regeneration by controlled opening of the canopy. Harvesting generates different microenvironments which present dissimilar conditions for seedling establishment, due to positive or negative influences over biotic and abiotic factors.

- Aims This study evaluated seedling survival and performance in different microenvironments within the harvested stands. Tested hypotheses stated that seedling stress and performance were influenced by harvesting due to changes in
\end{abstract}

\footnotetext{
Handling Editor: Andreas Bolte

Contribution of the co-authors G. Martínez Pastur coordinates the research project, designs the experiments, and writes the paper together with P.L. Peri and M.G. Neyland. R. Soler Esteban and J.M. Cellini worked in the data taking and data analyses under the supervision of M.V. Lencinas, who conducted the statistical data analysis.
}

G. J. M. Pastur $(\bowtie) \cdot$ R. S. Esteban • M. V. Lencinas

Centro Austral de Investigaciones Científicas (CONICET),

Houssay 200, (9410) Ushuaia, Tierra del Fuego, Argentina

e-mail: gpastur@conicet.gov.ar

\section{J. M. Cellini}

Laboratorio de Investigaciones de Sistemas Ecológicos y

Ambientales (LISEA-UNLP), Diagonal 113 n 469, (1900) La Plata,

Buenos Aires, Argentina

P. L. Peri

Instituto Nacional de Tecnología Agropecuaria, Universidad

Nacional de la Patagonia Austral - CONICET, cc 332, (9400)

Río Gallegos, Santa Cruz, Argentina

M. G. Neyland

Forestry Tasmania, GPO Box 207, Hobart, Tasmania 7001, Australia forest structure, microclimate, soil properties, and nutrient availability.

- Methods In the stands harvested by variable retention, five contrasting microenvironments were selected as treatments for the experiments and sampling. Environmental variables were related to ecophysiological, seedling survival, and performance.

- Results The modification of forest structure (crown cover and tree density) and the presence of coarse woody debris greatly affect the effective rainfall and global radiation reaching understorey level, influencing seedling stress and consequently survival and performance. Harvesting also modifies soil properties (e.g., soil bulk density) and coarse woody debris accumulation which in turn influences soil moisture and/or solar radiation levels. Analyses showed that seedlings received benefits of microenvironment variation after harvesting. Areas covered with middle or fine woody debris presented regeneration with better ecophysiological response and seedling performance, although dispersed retention areas (far away from remnant trees) and roads could also present suitable conditions for seedling survival and performance.

- Conclusions The proportion of different microenvironments in the harvested forests will determine the amount of natural recruitment of regeneration and consequently the success of proposed silvicultural management. Forest practices must be manipulated to increase the proportion of favorable microenvironments (e.g., woody debris), allowing greater natural regeneration success during the first years after harvesting.

Keywords Aggregated retention - Dispersed retention . Microenvironments $\cdot$ Light availability $\cdot$ Soil moisture · Soil properties 


\section{Introduction}

Current silvicultural prescriptions for the harvesting of Nothofagus pumilio forests in southern Patagonia are mainly based on canopy opening that stimulates natural regeneration by modifying soil moisture and light availability at ground level (Rosenfeld et al. 2006). Seedling growth conditions are improved when the canopy is gradually opened, as naturally occurs in a gap dynamic system (Wardle 1970). However, if the opening is increased abruptly in Nothofagus forests, the effective sheltering function of the remnant overstorey can be diminished (Howard 1973). Also, overstorey canopy cover determines the effective rainfall that reaches the forest floor and consequently the soil moisture content, which improves seedling performance at moderate canopy cover levels (40$60 \%$ ) in N. pumilio forests (Martínez Pastur et al. 2011a). However, under extreme canopy opening (>60\%), the solar radiation intensity at the ground level also increases, which can result in greater evaporation rates, reducing soil moisture below critical values. Both effects determine seedling performance during the establishment stage, e.g., in Fagus sylvatica (Ammer et al. 2008). In particular, young seedlings of $N$. pumilio have been demonstrated to be sensitive to soil moisture (Heinemann et al. 2000; Heinemann and Kitzberger 2006).

Increasingly, structural retention silvicultural systems (e.g., variable retention) that maintain elements of the original forest are being designed to meet multiple objectives (e.g., biodiversity conservation, natural cycles, timber production values, and wildlife habitat) (Gustafsson et al. 2012; Lindenmayer et al. 2012; Neyland et al. 2012). Variable retention harvesting has been increasingly applied in south Patagonia over the last 10 years in N. pumilio forests, usually as a mix of aggregated and dispersed retention. These retention patterns can influence microclimate (e.g., radiation, temperature, or soil moisture) and other physical processes, which differ substantially between harvested and non-harvested areas (Heithecker and Halpern 2007). This harvesting system generates a high spatial variation in the remnant forest structure within the harvested stands; however, the heterogeneity of understorey cover, microtopography, and edaphic properties (e.g., organic matter) are likely to be more important than overstorey structure for tree seedling performance (Martínez Pastur et al. 2011b).

Natural forests present a great variability of microenvironments at the understorey level, offering different microhabitat conditions for survival and growth of tree regeneration (Martínez Pastur et al. 2012). However, harvesting modifies the forest structure and impacts both biotic and abiotic natural components (e.g., understory plants and forest soil), generating a different assemblage and availability of microenvironments. These microenvironments in the harvested stands present dissimilar conditions for seedling establishment and performance, due to their differential influences (positive or negative) on the biotic and abiotic factors described above (Kupferschmid and Bugmann 2005; Blood and Titus 2010). In this study, the objective was to evaluate seedling survival and performance under different microenvironmental conditions within the harvested stands during the establishment stage. Based on such information, silvicultural prescriptions may be developed to successfully regenerate $N$. pumilio without clearing the site and thus completely changing the environmental conditions. For this purpose, we tested the following hypotheses: (1) the remnant overstorey following variable retention harvesting (comprising both aggregates and dispersed trees) influences microclimate particularly through rainfall and solar radiation interception at ground level and consequently affects seedling stress and performance, (2) harvesting modifies soil properties and nutrient availability and consequently affects seedling performance, and (3) extreme values (low and high) of soil water content and/or solar radiation negatively affect seedling performance.

\section{Methods}

\subsection{Study site and climate characterization}

The study site was located in a pure natural $N$. pumilio forest on Tierra del Fuego Island (Argentina), harvested using variable retention (Martínez Pastur et al. 2011b). This method retained aggregates (one circular aggregate of $30-\mathrm{m}$ radius per hectare) and dispersed dominant trees (basal area 10 $15 \mathrm{~m}^{2} \mathrm{ha}^{-1}$ ) evenly distributed between the retained aggregates, as remnant overstorey after the harvesting. The forest was located in Los Cerros Ranch (Fig. 1), and the experiments were established in three stands harvested 2-4 years ago (stand $1=2$ years, stand $2=3$ years, and stand $3=4$ years). Stand 1 (15 ha) presented $10 \%$ slope and north aspect, stand 2 (22 ha) presented $15 \%$ slope and northeast aspect, and stand 3 (27 ha) presented $9 \%$ slope and east aspect. The studied stands were of middle-to-high site quality according to Martínez Pastur et al. (1997), have a total overbark volume of $700-900 \mathrm{~m}^{3} \mathrm{ha}^{-1}$, and have total dominant heights of $20.5-27.5 \mathrm{~m}$.

The climate was characterized by short, cool summers and long, snowy and frozen winters. Only 3 months per year was free of mean daily temperatures under $0{ }^{\circ} \mathrm{C}$, and the growing season was approximately 5 months. Rainfall including snowfall reached up to $600 \mathrm{~mm}$ year $^{-1}$. Annual average wind speed outside forests was $8 \mathrm{~km} \mathrm{~h}^{-1}$, reaching up to $100 \mathrm{~km} \mathrm{~h}^{-1}$ during storms (Martínez Pastur et al. 2011b).

To characterize the microclimate within the variable retention harvests, ten data loggers (model H8, HOBO, USA) were used over the study period (1 October to 31 March) (two data loggers per treatment (see below) distributed along the three 
Fig. 1 Location of the study area (cross mark) at Los Cerros Ranch (Tierra del Fuego, Argentina). Forests were classified to (1) Nothofagus antarctica forests (pale gray), (2) N. pumilio forests (gray), and (3) mixed evergreen $N$. betuloides and deciduous $N$. pumilio forests (black)

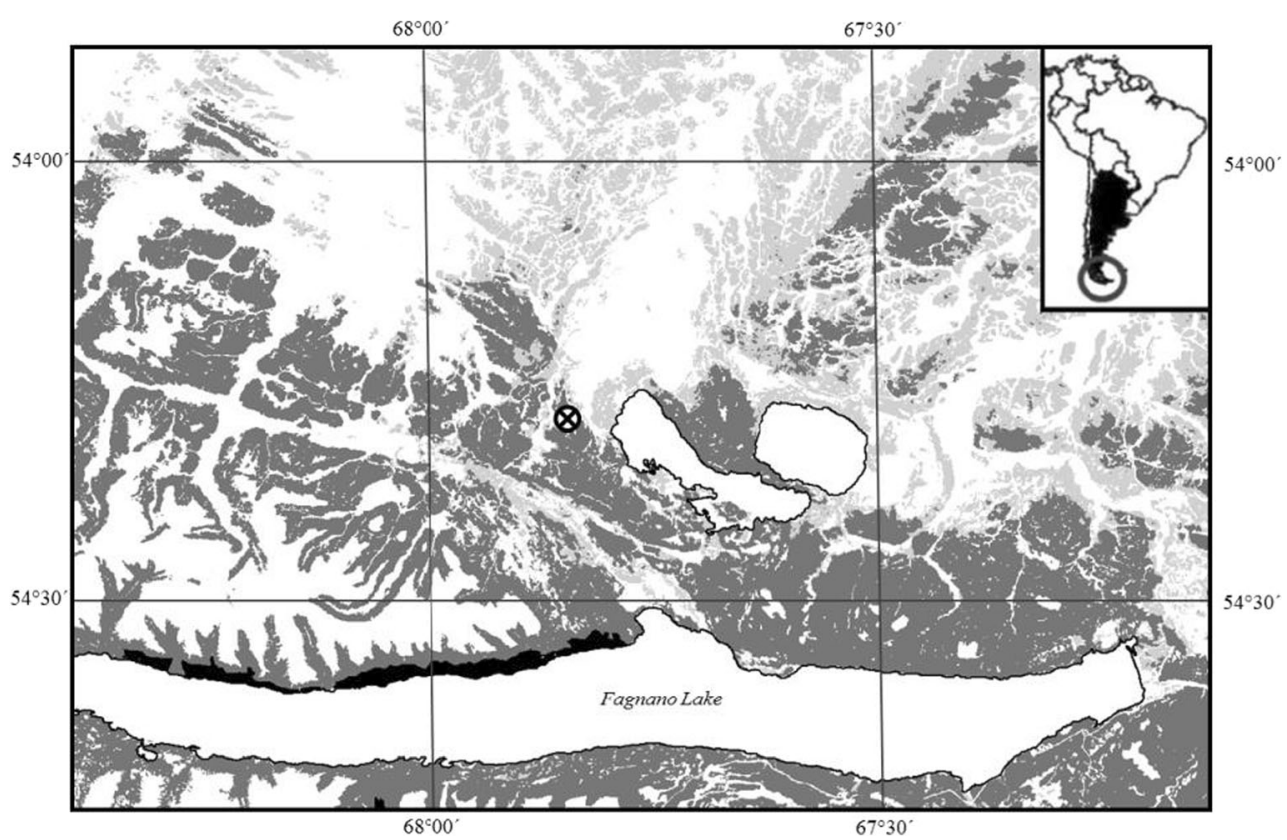

studied stands), to measure air temperature at $1 \mathrm{~m}$ height and soil temperatures at $30 \mathrm{~cm}$ depth. To quantify rainfall during the same period, one weather station (Weather Wizard III and accessories, Davis Instruments Corp., USA) was placed within one open area in stand 2.

\subsection{Seedling experiments}

In the harvested stands, five contrasting microenvironments were selected as treatments for the experiments, which were related to retention types and the degree of impact of harvesting operations: (1) within the retained aggregates (AR), (2) in the dispersed retention (DR) beyond the influence of aggregated retention ( $>20 \mathrm{~m}$ of edges), (3) in the dispersed retention and under the influence of remnant overstorey trees $(<2 \mathrm{~m}$ from the base of a retained tree) (RT), (4) in the dispersed retention under middle or fine woody debris $(<10 \mathrm{~cm}$ in diameter) resulting from the harvesting (D), and (5) in the dispersed retention over secondary roads produced by skidders during logging (R). We chose $2 \mathrm{~m}$ distance from the base of the retained trees, due to the fact that in this area, the soil moisture presented was on average significantly lower compared to higher distances (see Martínez Pastur et al. 2011b). The percentage of area occupied by each microenvironment was estimated using a $5 \times 5 \mathrm{~m}$ systematic grid over 1 ha for each stand, and main understorey plant groups and plants were identified according to the proposals of Soler Esteban et al. (2012).

Three thousand 2-year-old seedlings were collected from the understorey seedling bank of an unmanaged primary forest located $0.8-1.1 \mathrm{~km}$ away from the studied stands. Seedlings were collected during the last week of September 2008 before budburst occurred and were carefully manually removed from the O-horizon of the forest floor. The seedlings ranged from 2 to $4 \mathrm{~cm}$ in height with 4-6 $\mathrm{cm}$ root length. Groups of seedlings $(n=50)$ were randomly identified with color bands and immediately manually transplanted to the study plots (three stands $\times$ five treatments $\times$ four replicates), where these were regularly and homogeneously distributed. Plots $\left(1 \mathrm{~m}^{2}\right.$ for the 50 seedlings) were identified by numbered tags and were located in homogeneous patches with similar understorey plant influence (less than $50 \%$ cover) representing the selected treatments within the previously surveyed hectare.

\subsection{Microenvironment characterization in the harvested stands}

To characterize canopy structure and solar radiation transmission, hemispherical photographs of forest canopy were taken in each plot at ground level with an 8-mm fish eye lens (Sigma, Japan) mounted on a $35 \mathrm{~mm}$ digital camera (Nikon, Japan) with a tripod leveling head to ensure horizontal lens position. Each photograph was orientated with the upper edge towards the magnetic north, avoiding direct sunshine under evenly overcast skies or cloudless days. Gap Light Analyzer software v.2.0 (Frazer et al. 2001) was used to define cover (overstorey crown and debris) (CC), as a percentage of open sky relative to the cover, and global radiation (GR) at ground level, as the amount of direct and diffuse radiation transmitted through canopy and debris. The user-supplied input variables and radiation details were presented in Martínez Pastur et al. (2011a). CC combines the effect of canopy cover of the overstory trees and the effect of cover of coarse woody debris on the forest floor. We combine the two variables due to the 
influence of coarse woody debris being significant under D treatment.

In each seedling plot, forest floor samples were taken from the O-horizon (after previously removing the litter layer) (0$10 \mathrm{~cm}$ ) during middle summer. Two samples were taken with a field borer, one for soil bulk density (SD) and one for laboratory analysis. Samples were weighed after air-drying for a week in laboratory conditions $\left(24{ }^{\circ} \mathrm{C}\right)$. The samples for the laboratory analysis were sieved through a $2 \mathrm{~mm}$ mesh to obtain the fineearth fraction. The following soil properties and nutrient contents were analyzed: (1) $\mathrm{pH}$ in water (1:2.5); (2) cation exchange capacity (CEC) using saturation with sodium acetate, washed with ethyl alcohol displacement through $\mathrm{pH} 7$ buffered ammonium acetate, and sodium determination using an inductively coupled plasma atomic emission spectrometer (ICPS Shimadzu 1000III, Japan); (3) total organic carbon (C) from soil samples washed with $\mathrm{HCl}(50 \%)$ with an automatic analyzer (LECO CR12, US); (4) total nitrogen (N) by a semi-micro Kjeldahl method; (5) extractable phosphorous (P) according to the method of Bray and Kurtz (1945); and (6) potassium (K) and magnesium $(\mathrm{Mg})$ using a displacement method through $\mathrm{pH} 7$ buffered ammonium acetate and determined using an inductively coupled plasma atomic emission spectrometer (ICPS Shimadzu 1000III, Japan). Nutrient contents were expressed in milligrams per cubic centimeter using concentration and bulk soil density from each plot. Volumetric soil water content (VSW) was determined with an MP406 moisture probe (ICT, Australia) for the three different studied months (November, January, and March) at midday during sunny days. Two measurements were taken in every plot and then averaged for the analysis (pair data of three stands $\times$ five treatments $\times$ four replicates $\times 3$ months).

\subsection{Seedling height monitoring}

Additional sampling using naturally regenerated seedlings was conducted in order to analyze the long-term effect of the microenvironments on height growth. To characterize the natural seedling height in the studied treatments, 17,523 data pairs (height and age) of seedlings were used $(A R=10,556$ data pairs, $\mathrm{DR}=4,871$ data pairs, $\mathrm{RT}=624$ data pairs, $\mathrm{D}=1$, 010 data pairs, $\mathrm{R}=462$ data pairs). Data was obtained from the monitoring program established in the long-term Tierra del Fuego plots (Gustafsson et al. 2012; Lindenmayer et al. 2012) over the first 8 years after variable retention harvesting (San Justo Ranch, $54^{\circ} 06^{\prime} \mathrm{S}, 68^{\circ} 37^{\prime} \mathrm{W}$ established in 2001 and Los Cerros Ranch, $54^{\circ} 18^{\prime} \mathrm{S}, 67^{\circ} 49^{\prime} \mathrm{W}$ established in 2004).

\subsection{Measurements in the seedling experiments}

Destructive seedling sampling was conducted in each plot 60 days (November), 120 days (January), and 180 days (March) after the experiment began. Survival rate (SR) was determined in each plot before the destructive sampling. Four seedlings were selected at random from each plot at dawn and midday to measure water potential in the field and determine the leaf water potential (LWP) using a Scholander pressure chamber (Model 600, PMS Instrument Co., USA) on the 2-cm top shoot of each seedling. For the same plants, total height $(H)$, root length (RL), number of leaves $(L)$, and leaf area (LA) were measured. The above- and below-ground components of each plant (leaves, stems, and roots) were separated and then dried in a forced draft oven at $65{ }^{\circ} \mathrm{C}$ to constant weight before weighing to determine biomass $( \pm 0.0001 \mathrm{~g})$.

\subsection{Statistical analysis}

Nested ANOVAs were done using (1) treatments (AR, RT, DR, $\mathrm{D}$, and $\mathrm{R}$ ) as main factor and stands $(1,2$, and 3 ) as nested factor (random) within treatment factor (fixed) to analyze environmental variables $(\mathrm{CC}, \mathrm{VSW}$, and $\mathrm{GR})$ and soil properties $(\mathrm{pH}, \mathrm{CEC}$, $\mathrm{D}, \mathrm{C}, \mathrm{N}, \mathrm{P}, \mathrm{K}$, and $\mathrm{Mg}$ ) and (2) treatments and sampling months as main factors with stands $(1,2$, and 3$)$ as nested factor (random) within treatment factor (fixed) to analyze SR, LWP (at dawn and midday), biometric seedling variables ( $H, \mathrm{RL}, L$, and FA) and biomass including leaf weight (LW), stem weight (SW), root weight (RW), and total weight (TW). Interval data were analyzed for normality using the Shapiro-Wilk test $(p<0.01)$, and then, a post hoc Tukey's test was used for all mean comparisons $(p<$ 0.05 ). Finally, analyses with the seedling variables were performed using canonical correspondence analysis (CCA) (ter Braak and Smilauer 2002). The purpose of this test was to estimate components of variance contributed by the environmental and soil property variables. The significance of the direct gradient CCA ordination was tested using Monte Carlo techniques. In the ordination, plots were classified according to treatments.

\section{Results}

\subsection{Microenvironment and microclimate characterization}

In the variable retention harvested stands, retained aggregates occupied $23.7 \pm 2.3 \%$ (average \pm standard deviation) of the harvested area. In the dispersed retention areas, most of the surface was covered by debris $(40.4 \pm 8.4 \%)$ or was affected by skidder roads $(17.4 \pm 6.0 \%)$ when timber logs were extracted, or was under the influence of the retained trees $(3.0 \pm 1.3 \%)$. The area well away from remnant overstorey trees beyond the influence of roads or debris accumulation (DR) occupied $15.4 \pm 1.6 \%$. This

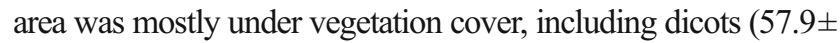
$24.7 \%$ ) of less than 30-cm height (Galium aparine > Osmorhiza depauperata $>$ Dysopsis glechomoides $>$ Acaena ovalifolia $>$

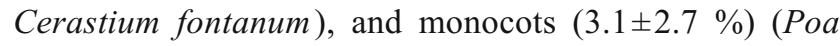
pratensis $>$ Uncinia lechleriana $>$ Phleum alpinum $)$. The 
remaining area was bare soil or litter without vegetation cover $(39.0 \pm 26.0 \%)$.

Accumulated net rainfall in open areas was homogeneous over the study period (growing season 2008-2009) with $1.4 \mathrm{~mm} \mathrm{day}^{-1}$ on average (Fig. 2). Despite this, two small periods without rainfall were observed ( 15 days from 13 to 27 November and 14 days from 29 November to 12 December). Air and soil temperatures increased during the first 2 months (October and November) and suddenly decreased at the end of summer (March) (Fig. 2). In the aggregated retention, mean daily air temperature was $8.5 \pm 2.8^{\circ} \mathrm{C}$ with a maximum of $15.4^{\circ} \mathrm{C}$, while mean daily soil temperature was $7.1 \pm 1.5^{\circ} \mathrm{C}$ with a maximum of $10.5^{\circ} \mathrm{C}$. In areas close to remnant overstorey trees, mean daily air temperature was $9.9 \pm 2.8^{\circ} \mathrm{C}$ with a maximum of $16.0^{\circ} \mathrm{C}$, while mean daily soil temperature was $9.6 \pm$ $2.0^{\circ} \mathrm{C}$ with a maximum of $13.2{ }^{\circ} \mathrm{C}$. In the dispersed retention, mean daily air temperature was $9.5 \pm 2.8^{\circ} \mathrm{C}$ with a maximum of $16.0^{\circ} \mathrm{C}$, while mean daily soil temperature was $9.1 \pm 1.6^{\circ} \mathrm{C}$ with a maximum of $11.8^{\circ} \mathrm{C}$. Under debris, mean daily air temperature was $8.4 \pm 2.9^{\circ} \mathrm{C}$ with a maximum of $15.1^{\circ} \mathrm{C}$, while mean daily soil temperature was $6.8 \pm 1.7^{\circ} \mathrm{C}$ with a maximum of $11.0^{\circ} \mathrm{C}$. Finally, in the dispersed retention over secondary roads, mean daily air temperature was $8.7 \pm 2.8^{\circ} \mathrm{C}$ with a maximum of $15.2^{\circ} \mathrm{C}$, while mean daily soil temperature was $8.7 \pm 1.7^{\circ} \mathrm{C}$ with a maximum of $11.5^{\circ} \mathrm{C}$.

Significant differences were found between treatments when environmental variables were analyzed (Table 1). Overstorey crown and debris cover (CC) peaked inside the aggregates (AR) and reached lower values in the dispersed retention and secondary roads (DR and R), with intermediate values in the other treatments. $\mathrm{CC}$ influenced other studied variables, so GR presented a similar but inverse pattern $(\mathrm{R}=\mathrm{DR}>\mathrm{RT}>\mathrm{D}>\mathrm{AR})$, while VSW presented a different pattern $(\mathrm{R}=\mathrm{D}=\mathrm{DR}>\mathrm{AR}=$ $\mathrm{RT})$. The relationship between these last two variables showed a clear difference between treatments (Fig. 3a), where (1) aggregated retention presented lower values for both variables; (2) the
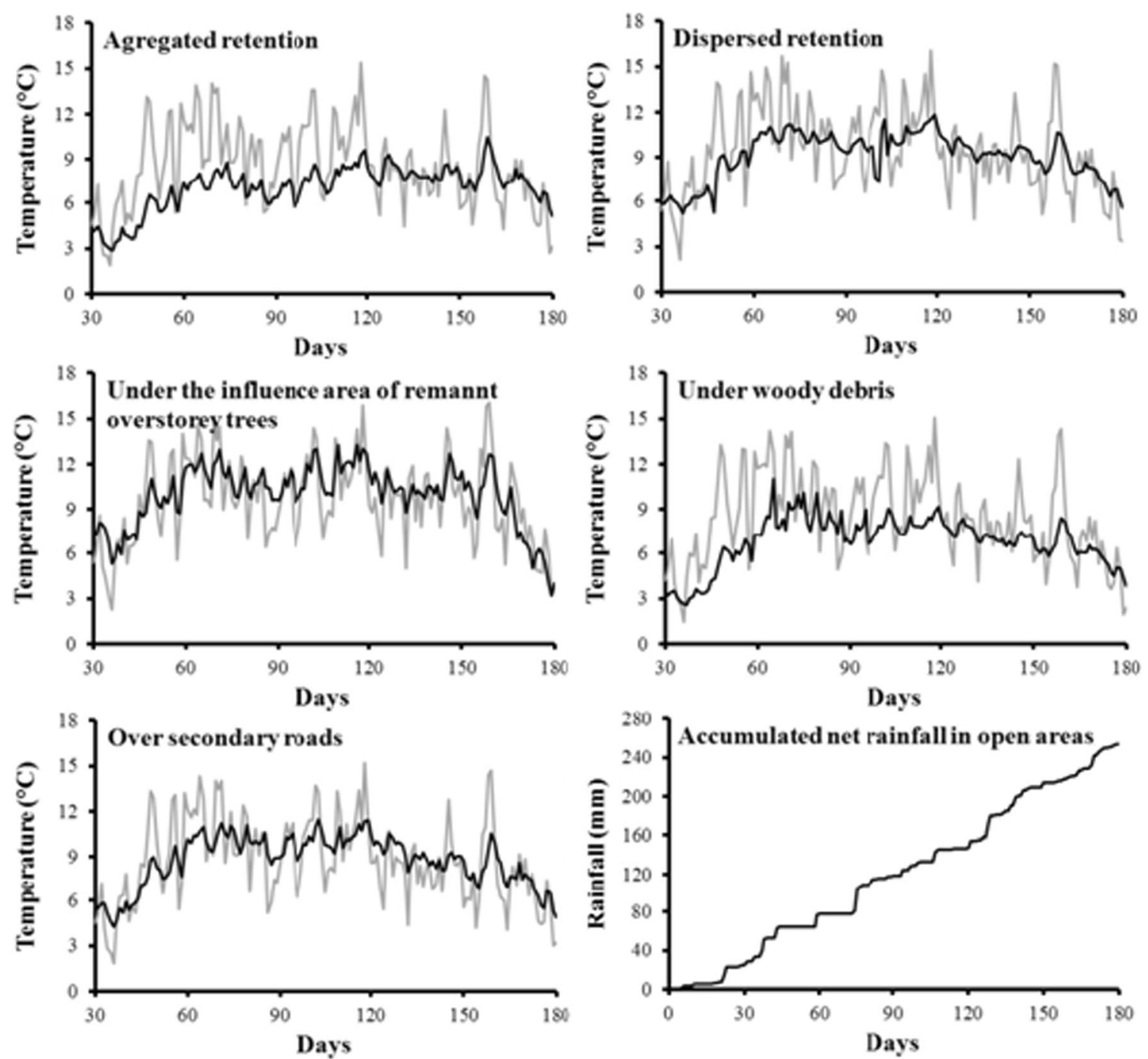

Fig. 2 Mean air temperature (gray) and mean soil temperature (black) over the study period (1 October to 31 March) in the different treatments, and accumulated net rainfall in open areas 
Table 1 Nested ANOVAs and means for treatments (AR = aggregated retention, $\mathrm{DR}=$ dispersed retention, $\mathrm{RT}=$ under the influence area of remnant overstorey trees, $\mathrm{D}=$ under woody debris, $\mathrm{R}=$ over secondary roads) for the volumetric soil water content (VSW) (percent), crown and debris cover (CC) (percent), global radiation (GR) (watts per square meter), soil acidity $(\mathrm{pH})$, cation exchange capacity (CEC) (milliequivalents per $100 \mathrm{~g}$ ), soil bulk density (SD) (grams per cubic centimeter), and nutrient soil content of organic carbon (C) (milligrams per cubic centimeter), total nitrogen $(\mathrm{N})$ (milligrams per cubic centimeter), phosphorous (P) (milligrams per cubic centimeter), potassium (K) (milligrams per cubic centimeter), and magnesium (Mg) (milligrams per cubic centimeter)

\begin{tabular}{lcccccccccccccc}
\hline Factor & & VSW & CC & GR & pH & CEC & SD & C & N & P & K & Mg \\
\hline \multirow{2}{*}{ Treatment } & AR & $13.66 \mathrm{a}$ & $78.56 \mathrm{c}$ & $7.88 \mathrm{a}$ & 5.92 & 16.52 & 0.58 & 78.3 & 2.36 & 0.07 & 0.25 & 0.45 \\
& $\mathrm{DR}$ & $29.33 \mathrm{~b}$ & $45.75 \mathrm{a}$ & $25.74 \mathrm{c}$ & 6.08 & 15.70 & 0.66 & 69.5 & 2.72 & 0.08 & 0.24 & 0.50 \\
& $\mathrm{RT}$ & $11.61 \mathrm{a}$ & $59.81 \mathrm{ab}$ & $18.84 \mathrm{bc}$ & 6.01 & 18.15 & 0.61 & 100.9 & 3.35 & 0.07 & 0.26 & 0.50 \\
& $\mathrm{D}$ & $31.49 \mathrm{~b}$ & $76.2 \mathrm{bc}$ & $12.88 \mathrm{ab}$ & 5.82 & 16.10 & 0.65 & 94.4 & 3.05 & 0.08 & 0.27 & 0.48 \\
& $\mathrm{R}$ & $35.39 \mathrm{~b}$ & $44.30 \mathrm{a}$ & $26.75 \mathrm{c}$ & 5.83 & 15.24 & 0.83 & 85.7 & 3.11 & 0.08 & 0.29 & 0.51 \\
& $F$ & 17.74 & 21.02 & 18.68 & 1.29 & 3.99 & 2.72 & 1.01 & 0.21 & 0.53 & 0.50 & 0.16 \\
& $(p)$ & $<0.001$ & $<0.001$ & $<0.001$ & 0.337 & 0.035 & 0.091 & 0.444 & 0.924 & 0.719 & 0.734 & 0.956 \\
Treatment (stand) & $F$ & 2.06 & 3.89 & 3.25 & 1.29 & 0.45 & 1.15 & 1.10 & 9.35 & 1.82 & 0.76 & 1.78 \\
& $(p)$ & 0.005 & $<0.001$ & 0.003 & 0.262 & 0.915 & 0.3458 & 0.385 & $<0.001$ & 0.085 & 0.661 & 0.092 \\
& & & & & & & & & & & & & &
\end{tabular}

Letters indicate differences using Tukey's test $(p=0.05)$, while no letter means no significant difference

Treatment (stand) nested effect (random) of stand factor within treatment (fixed), $F$ Fisher's test, $(p)$ probability

Fig. 3 a Environmental conditions (volumetric soil water content (VSW) and global radiation (GR)) and b survival rate for the studied period (1 October to $31 \mathrm{March}$ ) in the different treatments: $\mathrm{AR}=$ aggregated retention, $\mathrm{DR}=$ dispersed retention, $\mathrm{RT}=$ under the influence area of remnant overstorey trees, $\mathrm{D}=$ under woody debris, and $\mathrm{R}=$ over secondary roads. Bars indicate \pm standard error
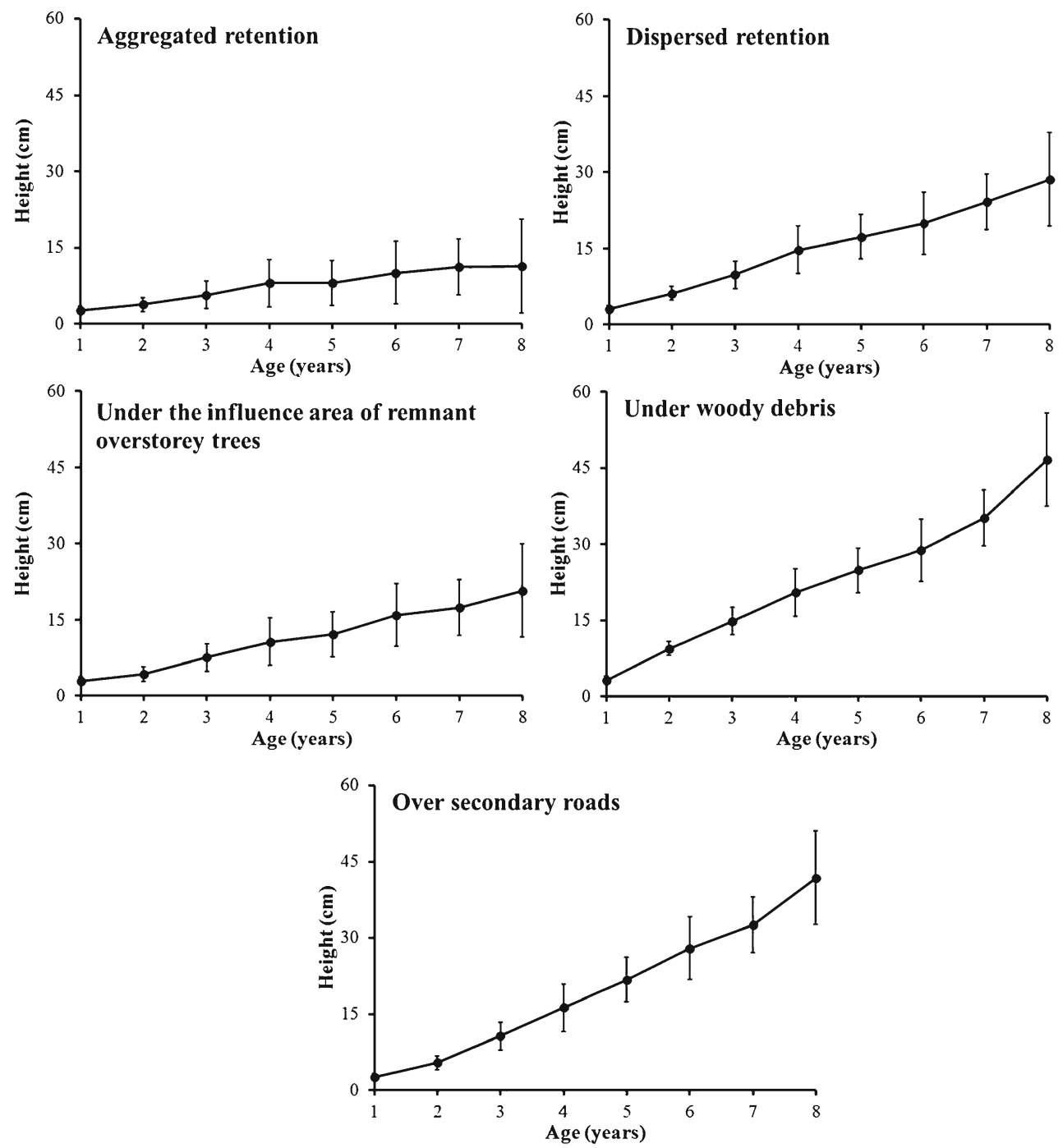
area under the influence of remnant overstorey trees had the same VSW but increased GR; (3) under debris, the same GR but increased VSW was observed compared to the aggregates; and (4) the other treatments (DR and R) increased VSW and GR compared to the aggregates. When soil properties were analyzed, only the CEC presented significant differences (Table 1) in the $F$ test, but not in the post hoc test. The random effects of the stands were significant for the three environmental variables and for the $\mathrm{N}$ content (Table 1), where stand 2 had greater crown cover and influenced the other values (GR and VSW) and stand $3 \mathrm{had}$ greater soil $\mathrm{N}$ content.

3.2 Seedling performance in the microenvironments of the harvested stands

Seedling height monitoring in the long-term plots showed different patterns during the first 8 years after harvesting (Fig. 4). The seedling heights were lower in the aggregated retention ( $11.4 \mathrm{~cm}$ at 8 years) compared to the harvested areas. In the dispersed retention, the areas under the influence of remnant overstorey trees presented lower values $(20.8 \mathrm{~cm}$ at 8 years), while under debris, the highest values were recorded ( $46.7 \mathrm{~cm}$ at 8 years). The other treatments (dispersed retention and secondary roads) had intermediate values (28.6 and $41.8 \mathrm{~cm}$ at 8 years, respectively).

Significant differences were found in the accumulated survival rate between treatments and months (Table 2). Survival was highest under debris, followed by secondary roads and aggregates, and lowest in dispersed retention and under the influence of remnant overstorey trees. Also, survival rate decreased over seasons. The higher mortality values arose at the beginning of the summer (Fig. 3b) in the treatments with higher losses (aggregates, under the influence of remnant overstorey trees, and dispersed retention) and presented the same mortality rates in the less affected treatments (debris and secondary roads). Leaf water potential (at dawn and midday) also presented significant differences between treatments and months (Table 2). At dawn, LWP presented lower values in the aggregates; intermediate under the influence of remnant overstorey trees, dispersed retention, and secondary roads; and higher values under debris. At midday, LWP presented lower values in aggregates and under the influence of remnant overstorey trees compared to the other treatments. The random effects of the stands and treatment $\times$ month interactions were significant for these three variables. These significant effects were explained through the differences in some environmental variables (CC and VSW) among the stands.

The major differences between LWP mean values of dawn and midday were found under the influence of remnant overstorey trees $(-0.63 \mathrm{MPa})>$ under debris $(-0.52 \mathrm{MPa})>$ dispersed retention $(-0.45 \mathrm{MPa})>$ aggregates $(-0.39 \mathrm{MPa})>$ secondary roads ( $-0.33 \mathrm{MPa}$ ) (for example, see Figs. 5 and 6). LWP values decreased during middle summer (January) compared to late spring and late summer, both at dawn and midday for aggregates and under the influence of remnant overstorey trees and at dawn in the dispersed retention (Fig. 5). The highest differences between dawn and midday were found during November ( $-0.66 \mathrm{MPa}$ compared to $-0.37 \mathrm{MPa}$ during January and March). These differences increased in only one treatment through the seasons (under the influence of remnant overstorey trees), but decreased in the other treatments (Fig. 5). Also, the ratio between LWP at dawn and midday varied by season, where the major differences occurred during middle summer rather than late spring or late summer (Fig. 6).

Seedling performance values showed several differences between treatments and months (Table 2). Seedling height and root length showed differences over the seasons, increasing from November to March. Number of leaves and leaf area also varied seasonally, being higher during middle summer than during late spring or late summer. Number of leaves also showed differences between treatments: $A R=R T>D=R>$ DR. Biomass did not show significant differences between treatments, but significantly increased over the growing season. Most of the changes occurred between November and January/March (stem, root, and total weight), except leaf weight which presented significant differences just in March.
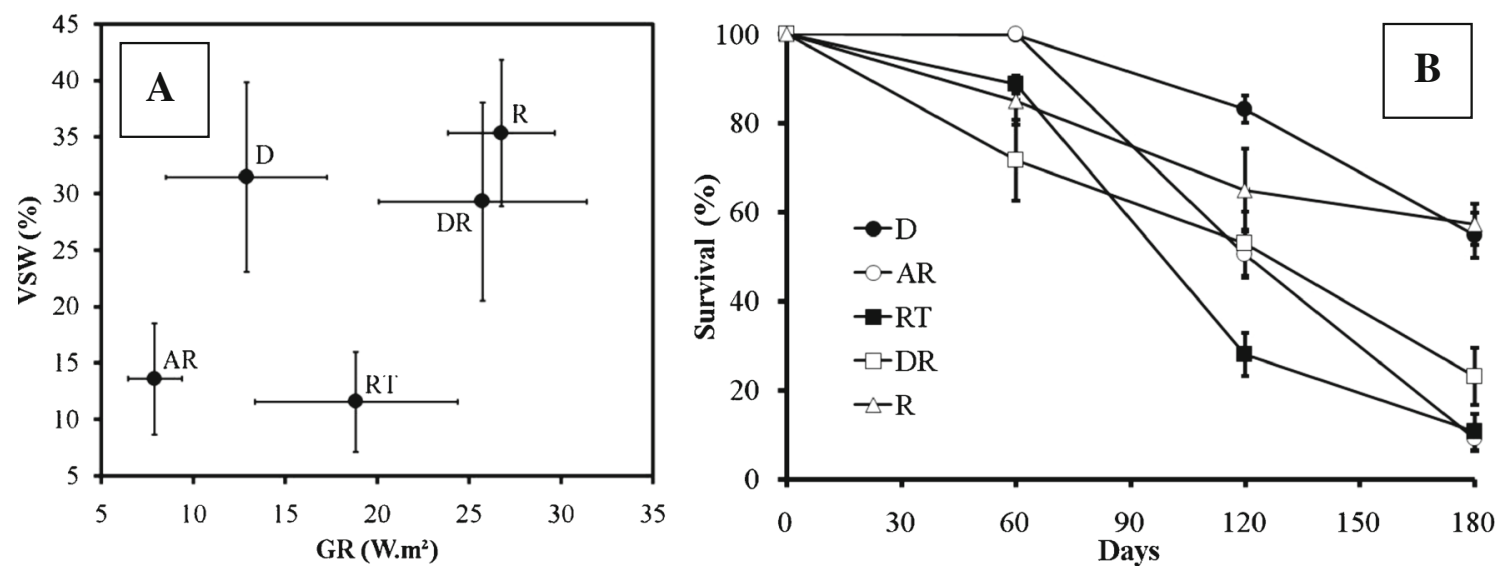

Fig. 4 Mean seedling height of plants growing in the different treatments during the first 8 years after harvesting. Bars indicate \pm standard deviation 
Table 2 Nested ANOVAs and means for treatments (AR = aggregated retention, $\mathrm{DR}=$ dispersed retention, $\mathrm{RT}=$ under the influence area of remnant overstory trees, $\mathrm{D}=$ under woody debris, $\mathrm{R}=$ over secondary roads) and months for survival rate (SR) (percent), leaf water potential at dawn (LWP-D) (megapascals) and at midday (LWP-M) (megapascals), height $(H)$ (centimeters), root length (RL) (centimeters), number of leaves $(L)$, leaf area (LA) (square centimeters), leaf weight (LW) (milligrams), stem weight (SW) (milligrams), root weight (RW) (milligrams), and total weight (TW) (milligrams)

\begin{tabular}{|c|c|c|c|c|c|c|c|c|c|c|c|c|}
\hline Factor & & SR & LWP-D & LWP-M & $\mathrm{H}$ & $\mathrm{RL}$ & $\mathrm{L}$ & LA & LW & SW & RW & TW \\
\hline \multirow[t]{7}{*}{ Treatment } & $\mathrm{AR}$ & $53.22 \mathrm{ab}$ & $-1.60 \mathrm{~b}$ & $-1.99 \mathrm{~b}$ & 4.48 & 5.93 & $2.94 \mathrm{a}$ & 2.40 & 14.4 & 28.5 & 32.7 & 75.6 \\
\hline & DR & $49.21 \mathrm{a}$ & $-1.12 \mathrm{ab}$ & $-1.56 \mathrm{a}$ & 4.57 & 6.73 & $4.17 \mathrm{~b}$ & 2.68 & 16.5 & 29.7 & 37.3 & 83.5 \\
\hline & RT & $42.57 \mathrm{a}$ & $-1.37 \mathrm{ab}$ & $-2.00 \mathrm{~b}$ & 4.30 & 6.26 & $3.21 \mathrm{a}$ & 2.55 & 16.7 & 25.4 & 33.2 & 75.2 \\
\hline & $\mathrm{D}$ & $79.31 \mathrm{~b}$ & $-0.82 \mathrm{a}$ & $-1.34 \mathrm{a}$ & 4.46 & 6.72 & $3.60 \mathrm{ab}$ & 3.25 & 18.2 & 29.0 & 39.42 & 86.7 \\
\hline & $\mathrm{R}$ & $69.05 \mathrm{ab}$ & $-0.92 \mathrm{ab}$ & $-1.26 \mathrm{a}$ & 4.59 & 6.85 & $3.69 \mathrm{ab}$ & 2.56 & 18.2 & 30.5 & 37.9 & 84.5 \\
\hline & $F$ & 6.06 & 4.06 & 3.74 & 1.63 & 2.00 & 6.25 & 0.83 & 0.44 & 1.07 & 0.78 & 0.65 \\
\hline & $(p)$ & 0.001 & 0.328 & 0.041 & 0.243 & 0.171 & 0.008 & 0.538 & 0.774 & 0.421 & 0.561 & 0.641 \\
\hline \multirow[t]{5}{*}{ Month } & November & $89.04 \mathrm{c}$ & $-1.08 \mathrm{a}$ & $-1.74 \mathrm{~b}$ & $4.08 \mathrm{a}$ & $5.53 \mathrm{a}$ & $3.17 \mathrm{a}$ & $2.37 \mathrm{a}$ & $14.5 \mathrm{a}$ & $21.7 \mathrm{a}$ & $26.0 \mathrm{a}$ & $62.3 \mathrm{a}$ \\
\hline & January & $55.96 \mathrm{~b}$ & $-1.47 \mathrm{~b}$ & $-1.84 \mathrm{~b}$ & $4.79 \mathrm{~b}$ & $7.06 \mathrm{~b}$ & $4.20 \mathrm{~b}$ & $3.47 \mathrm{~b}$ & $14.6 \mathrm{a}$ & $32.0 \mathrm{~b}$ & $42.0 \mathrm{~b}$ & $94.5 \mathrm{~b}$ \\
\hline & March & $31.04 \mathrm{a}$ & $-0.95 \mathrm{a}$ & $-1.31 \mathrm{a}$ & $4.57 \mathrm{~b}$ & $6.91 \mathrm{~b}$ & $3.20 \mathrm{a}$ & $2.22 \mathrm{a}$ & $20.3 \mathrm{~b}$ & $32.1 \mathrm{~b}$ & $40.2 \mathrm{~b}$ & $86.7 \mathrm{~b}$ \\
\hline & $F$ & 184.25 & 18.11 & 17.63 & 24.92 & 28.65 & 19.78 & 29.06 & 15.58 & 44.13 & 45.31 & 38.89 \\
\hline & $(p)$ & $<0.001$ & $<0.001$ & $<0.001$ & $<0.001$ & $<0.001$ & $<0.001$ & $<0.001$ & $<0.001$ & $<0.001$ & $<0.001$ & $<0.001$ \\
\hline \multirow[t]{2}{*}{ Treatment (stand) } & $F$ & 4.90 & 3.67 & 4.48 & 0.94 & 1.83 & 1.21 & 5.03 & 3.24 & 2.68 & 4.04 & 3.72 \\
\hline & $(p)$ & $<0.001$ & $<0.001$ & $<0.001$ & 0.503 & 0.059 & 0.289 & $<0.001$ & $<0.001$ & 0.005 & $<0.001$ & $<0.001$ \\
\hline \multirow[t]{2}{*}{ Treatment $\times$ month } & $F$ & 9.03 & 6.54 & 3.47 & 1.11 & 1.57 & 4.62 & 2.17 & 1.29 & 3.52 & 2.92 & 3.13 \\
\hline & $(p)$ & $<0.001$ & $<0.001$ & 0.001 & 0.357 & 0.138 & $<0.001$ & 0.325 & 0.253 & 0.009 & 0.053 & 0.003 \\
\hline
\end{tabular}

Letters indicate differences using Tukey's test $(P=0.05)$, while no letter means no significant difference

Treatment (stand) nested effect (random) of stand factor within treatment (fixed), Treatment $\times$ month main factor interactions, $F$ Fisher's test, $(p)$ probability

The random effects of the stands were significant for all the studied variables, while the treatment $\times$ month interaction was significant for number of leaves, stem, and total weight. As was explained before, these significant effects were explained through the differences in some environmental variables $(\mathrm{CC}$ and VSW), where stand 3 presented intermediate values of CC and showed lower mortality and higher seedling biomass values.

Canonical correspondence analyses with the seedling performance data determined the components of variance of the studied variables (environmental and soil properties) (Fig. 7), highlighting the relative impact over the growing season. In November, Monte Carlo tests showed the following significance for the studied variables ( $F$ ratio, probability): crown and debris cover $(21.35,0.002)>$ volumetric soil water content $(2.00,0.104)>\mathrm{P}(1.40,0.228)>\mathrm{N}(1.29,0.226)>\mathrm{Mg}$ $(1.12,0.296)>$ global radiation $(0.73,0.538)>$ soil bulk density $(0.57,0.606)>\mathrm{C}(0.55,0.610)>\mathrm{K}(0.45,0.778)>$ $\mathrm{pH}(0.44,0.762)>$ cation exchange capacity $(0.38,0.828)$. Eigenvalue and correlation of axis 1 were 0.040 and 0.732 and, for axis 2 , were 0.003 and 0.472 , while total inertia of the analysis reached 0.112. Aggregates and under debris plots were clearly separated by crown and debris cover effect on axis 1 , and both treatments were separated again by the volumetric soil water content on axis 2 . The other treatments were mainly explained by global radiation on axis 1 . In January, Monte Carlo tests showed the following significance for the variables: volumetric soil water content $(22.64,0.002)$ $>$ crown and debris cover $(4.56,0.010)>\mathrm{N}(2.99,0.034)>$ soil bulk density $(2.74,0.044)>$ cation exchange capacity $(2.18,0.092)>$ global radiation $(1.80,0.130)>\mathrm{Mg}(0.47$, $0.728)>\mathrm{K}(0.66,0.624)>\mathrm{P}(0.44,0.760)$, while $\mathrm{C}$ and $\mathrm{pH}$ were omitted. Eigenvalue and correlation of axis 1 were 0.037 and 0.770 and, for axis 2 , were 0.007 and 0.621 , while total inertia of the analysis reached 0.107 . On axis 1 , crown and debris cover separated aggregates and the areas under the influence of remnant overstorey trees, while volumetric soil water content, global radiation, and $\mathrm{N}$ separated the other treatments. On axis 2, crown and debris cover and global radiation separated the aggregates and under debris treatment from the others. In March, Monte Carlo tests showed the following significance for the variables: volumetric soil water content $(23.90,0.002)>$ global radiation $(3.28,0.024)>$ crown and debris cover $(2.50,0.038)>$ soil bulk density $(1.40,0.196)>\mathrm{K}(1.18,0.280)>\mathrm{N}(1.21,0.316)>\mathrm{pH}$ $(0.96,0.386)>$ cation exchange capacity $(0.67,0.596)>\mathrm{P}$ $(0.56,0.702)>\operatorname{Mg}(0.54,0.708)>\mathrm{C}(0.46,0.774)$. Eigenvalue and correlation of axis 1 were 0.038 and 0.765 and, for axis 2 , were 0.005 and 0.605 , while total inertia of the analysis reached 0.111 . On axis 1 , crown and debris cover 
Fig. 5 Leaf water potential (LWP) at dawn (gray line) and midday (black line) in 3 months over the study period (November, January, and March) in the different treatments. Bars indicate \pm standard error
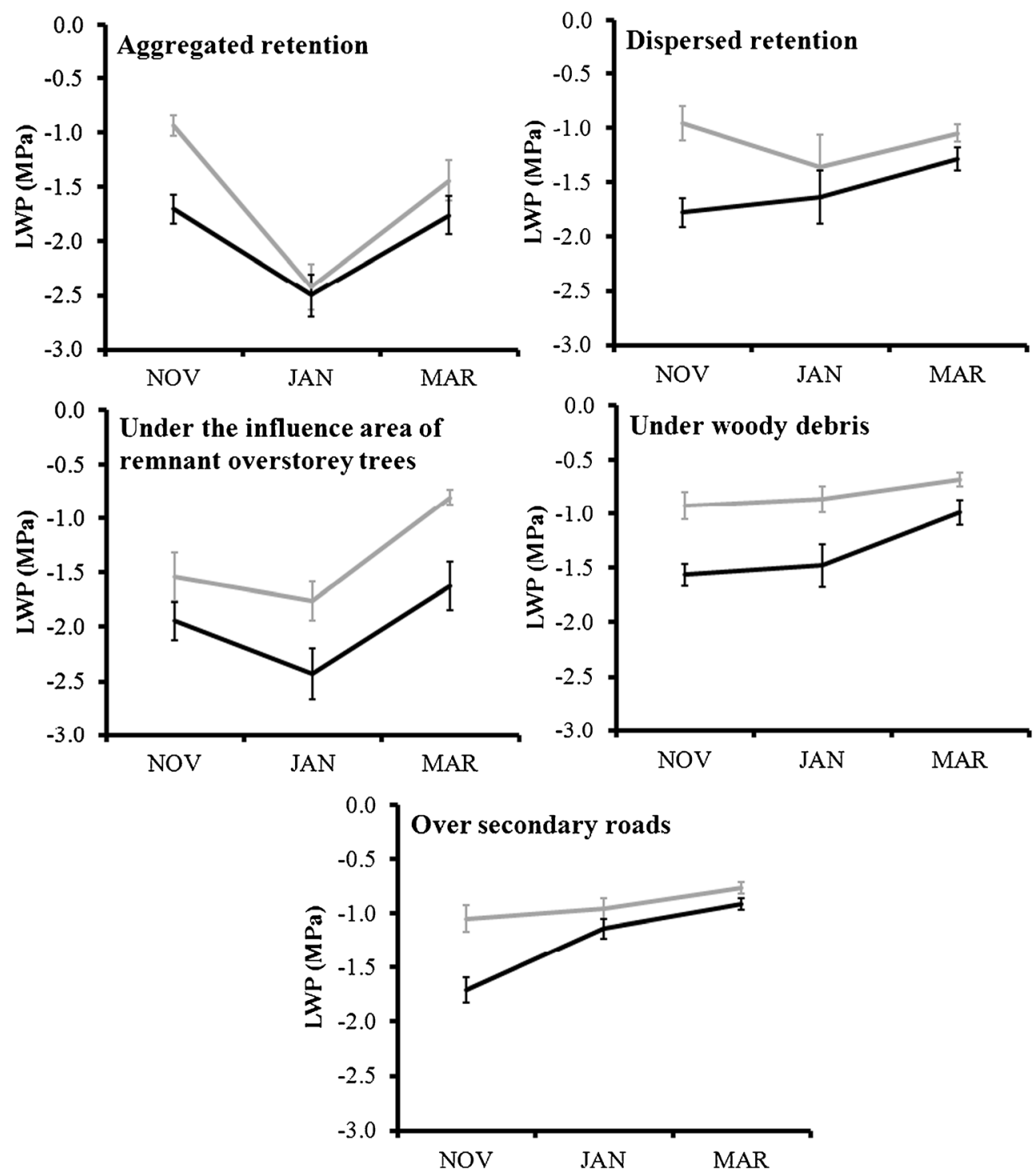

separated aggregates and the areas under the influence of remnant overstorey trees, while volumetric soil water content and global radiation separated the other treatments. On axis 2, all the variables poorly influenced the separation of the treatments.

\section{Discussion}

4.1 Remnant overstorey after harvesting changes microclimate and influences seedling performance

According to the observed results, the analyzed microenvironments were drastically altered by forest harvesting, showing different microclimate conditions related to soil moisture and light availability (VSW and GR). Harvesting modifies the microclimatic conditions in $N$. pumilio stands by altering the overstorey canopy (Caldentey et al. 2009). Overstorey interception of rainfall during summer is $25 \%$ in primary forests of N. pumilio (Frangi and Richter 1994) and close to $16 \%$ in harvested forests (with $50 \%$ canopy removal), where photosynthetically active radiation increased 2.4-2.9 times (Caldentey et al. 2009). Both factors (soil moisture and light availability) critically affect growth and survival of seedlings in these austral forests (Heinemann et al. 2000; Martínez Pastur et al. 2007). Aggregated retention presented similar climate values to primary forests due to the high crown cover of the overstorey, where aggregates also influence the surrounding harvested areas depending on the aspect and distance from the retention patches (Martínez Pastur et al. 2011b). These findings were also informed by Heithecker and Halpern (2007) and other studies that have explored the microclimatic effects of retention (e.g., Chen et al. 1999). Steep gradients in microclimate are typical along the boundary between recently harvested and original forests, where change usually occurs within 40-50 m of the edge (e.g., Chen et al. 
Fig. 6 Relationship between leaf water potential (LWP) at dawn and midday for the different treatments. Bars indicate \pm standard error

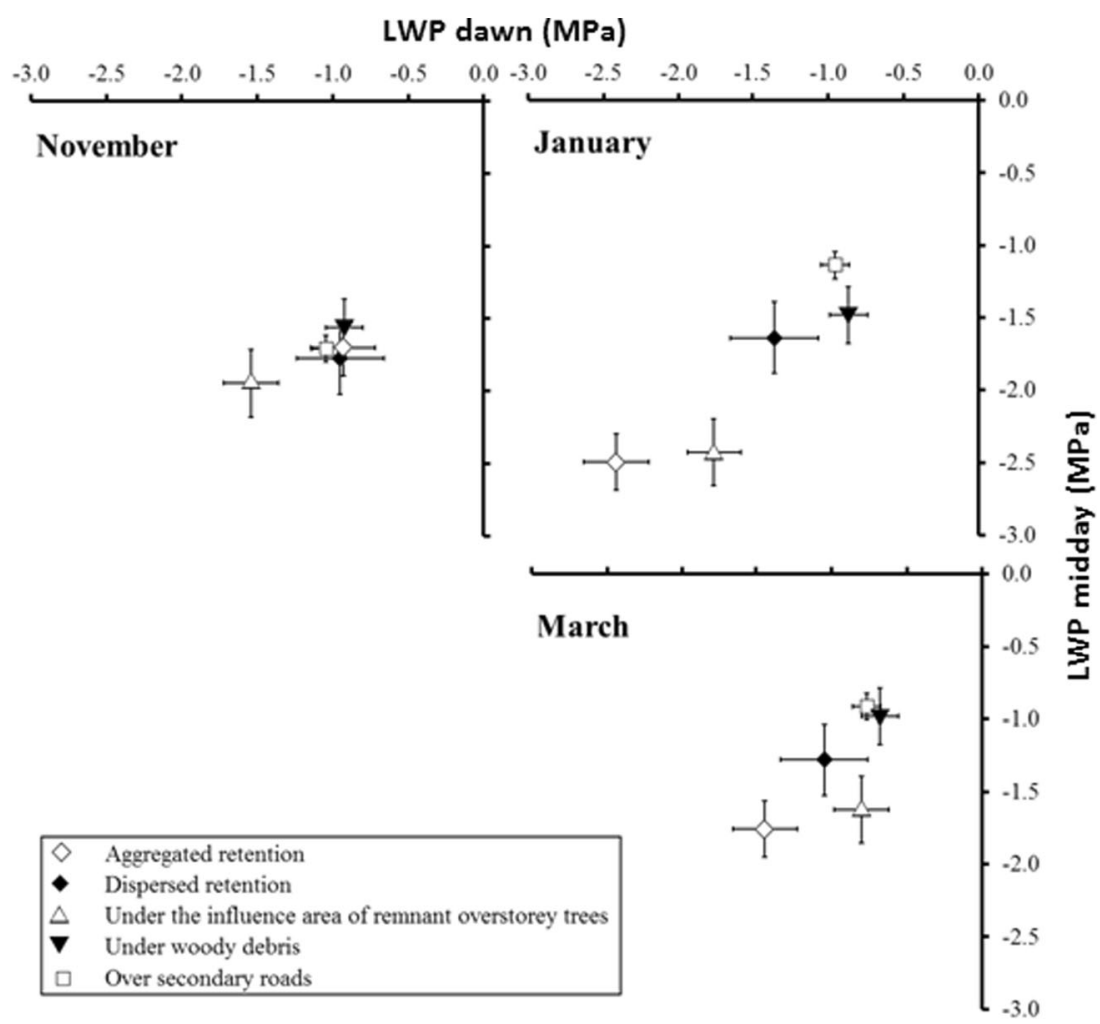

1995). However, some microclimatic variables (e.g., air humidity and wind speed) are highly sensitive to forest edges and effects can be detected at longer distances of $>200 \mathrm{~m}$ (e.g., Chen et al. 1995). In this study, we compared only the extreme conditions, (1) inside the aggregates at the middle of the nonharvested patches and (2) the most exposed harvested areas further away from the aggregates ( $40-45 \mathrm{~m}$ to the boundaries), and assume the existence of a gradient of soil moisture and light availability along the harvested areas, where the impacts diminish when boundaries are closer (e.g., Martínez Pastur et al. 2011b).

\subsection{Harvesting modifies soil properties' influence over seedling performance}

According to the observed results, the analyzed microenvironments were drastically altered by forest harvesting, showing different soil damage related to soil bulk density changes, but there were no significant differences in their chemical composition. Crown cover levels also varied among microenvironments. Some microenvironments had excessive cover that diminished seedling performance (e.g., AR and D), but most of the treatments presented the most beneficial cover levels for seedlings (Martínez Pastur et al. 2011a). Soil moisture was also influenced by specific microenvironments, e.g., roads can produce a pit effect, increasing the water accumulation which could act as a favorable condition during middle summer or as unfavorable condition during wet months (during thaw at the end of spring). Also, lower crown cover levels can increase soil moisture to undesirable levels and thus influence photosynthetic performance and biomass growth of seedlings (Martínez Pastur et al. 2007).

During late spring, forest soils are usually saturated due to winter snow thaw. In our work, we suggested that during November, light (CC vs. GR) is the limiting factor for growth seedling performance and plant moisture stress. In contrast, during middle (January) and late (March) summer, not only light availability was the limiting factor but also VSW was the key factor for regeneration performance. $N$. pumilio seedlings demonstrated a significant plasticity (Martínez Pastur et al. 2007), being able to grow in several microenvironment types, and are classified as a mid-tolerant species due to their colonization abilities (Gutiérrez 1994). These ecological features can explain the lack of influence of soil properties on the regeneration performance, except $\mathrm{N}$ and $\mathrm{Mg}$ soil content during middle summer. Probably, nutrients become relevant during middle summer due to a greater soil microbial activity (Caldentey et al. 2001).

4.3 Changes in soil water content after harvesting influence seedling moisture stress

Seedling stress increased from dawn to midday in all treatments and was mostly related to VSW rather than GR, except 

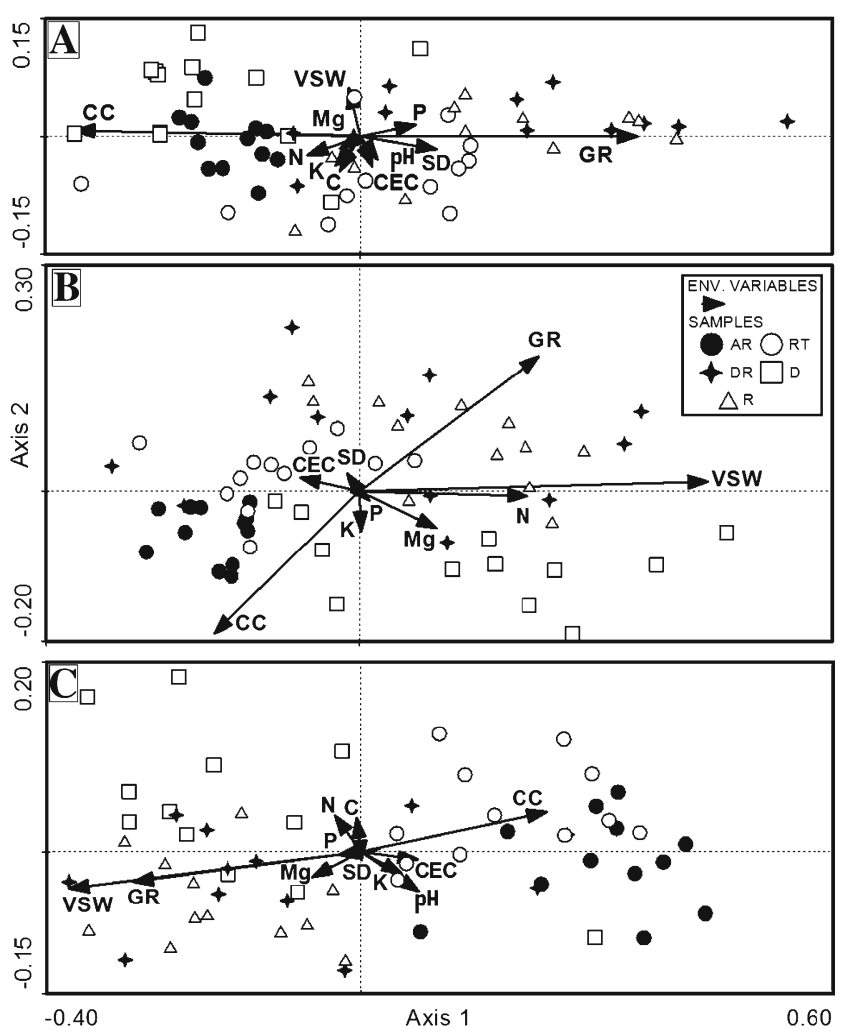

Fig. $7 \mathrm{CCA}$ analysis for the measured biometric and water potential variables of the regeneration during the growing season (a November, $\mathbf{b}$ January, and $\mathbf{c}$ March). Plots were classified according to the different treatments: $A R=$ aggregated retention, $D R=$ dispersed retention, $R T=$ under the influence area of remnant overstorey trees, $D=$ under woody debris, and $R=$ over secondary roads. Environmental explicatory variables were volumetric soil water content (VSW) (percent), crown and debris cover $(C C)$ (percent), global radiation $(G R)$ (watts per square meter), soil acidity $(p H)$, cation exchange capacity $(C E C)$ (milliequivalents per $100 \mathrm{~g}$ ), soil bulk density $(S D)$ (grams per cubic centimeter), and nutrient soil content of organic carbon $(C)$ (milligrams per cubic centimeter), total nitrogen $(N)$ (milligrams per cubic centimeter), phosphorous $(P)$ (milligrams per cubic centimeter), potassium $(K)$ (milligrams per cubic centimeter), and magnesium $(M g)$ (milligrams per cubic centimeter)

for debris. Seedling stress and VSW are inversely related near the influence of remnant trees (e.g., Palik et al. 2003), as was observed in the dispersed (RT) or aggregated retention (AR), and negatively influenced regeneration (e.g., survival rate). In contrast, debris and roads presented lower plant moisture stress values, both at dawn and midday, and decreased over seasons during the studied period. Debris acts as a positive shelter for regeneration; low stress was observed in plants growing with intermediate values of VSW. The benefits of debris were previously reported for Nothofagus (Heinemann et al. 2000) and other species in temperate and boreal forests (McCarthy 2001).

We expected higher seedling stress during the middle of summer, coincident with higher air temperatures and soil water depletion. However, some treatments presented lower plant moisture stress during summer and showed the highest seedling growth rates (e.g., debris and roads). In our work, roads (skid trails) not only increase the soil bulk density but also increase the soil moisture. The impact of skidders on soil properties is often reported (e.g., Modry and Hubeny 2003), but few works describe their potential benefits (e.g., on soil moisture, Buckley et al. 2003). Also, seedling mortality was higher under greater stress conditions (e.g., AR and RT) and higher during middle summer. During this period, seedling stress values between dawn and midday in the different microenvironments were more dissimilar (especially AR and RT) than in spring and late summer. This can be related to the higher air temperature values during midday, which produced an imbalance between water uptake from the soil and water loss through transpiration. Also, lower stress allows greater $\mathrm{CO}_{2}$ influx, favoring greater net photosynthesis (Fitter and Hay 2002) which may explain the greater growth in some treatments (e.g., D and R).

\subsection{Seedling performance in the different microenvironments}

Microenvironments influenced the survival rate of the regeneration, as did time period over the growing season. Higher values of survival rate under debris can be explained due to the extra shelter provided, increasing soil moisture and decreasing radiation. The presence of decaying coarse woody debris in gaps of $N$. pumilio forests in north Patagonia also increases survival rate due to the higher water availability during late summer (Heinemann et al. 2000). However, when regeneration grows, a switch occurs from water- to light-limited systems, and light can then be the limitation for growth in the following years (Heinemann et al. 2000; Heinemann and Kitzberger 2006; Ammer et al. 2008). Secondary roads also had a positive impact on regeneration survival rate. However, roads also have a potential negative impact due to the increment on soil bulk density with a middle-term potential effect. Survival rate abruptly decreased during summer in the other treatments (DR, AR, and RT), where lower values were found under aggregated retention and near remnant trees in the dispersed retention. Both treatments had lower soil moisture values, as the canopy retained most of the rainfall or through water uptake by remnant trees. Understorey influence was not considered in this study, but it can positively (e.g., Osmorhiza depauperata) or negatively (e.g., Acaena ovalifolia) influence survival and growth of $N$. pumilio seedlings, as reported by Martínez Pastur et al. (2011b). The influence of different plant groups (monocots, dicots, shrubs, ferns, and mosses) over establishment, survival, and growth of seedlings was also observed for Nothofagus betuloides regeneration (Martínez Pastur et al. 2012). In our study, mortality was mainly related to soil moisture, which was also identified as the main factor causing seedling loss in north Patagonian forests (Heinemann and Kitzberger 2006). Here, two factors influenced soil moisture and the observed survival rate: (1) the first was related to 
remnant overstorey (water uptake and rainfall interception) and (2) the second was the pit effect of roads (Frangi and Richter 1994; Schmidt et al. 1998). As was described before, seedling performance can be explained through the soil moisture, but solar radiation also greatly influences ecophysiological variables, plant architecture, and biomass allocation modifying seedling performance. For example, ecophysiological variables greatly changed along these gradients (Martínez Pastur et al. 2007), especially under moderate and severe drought (Peri et al. 2009). For example, some microenvironments are water limited (e.g., RT), others are light limited (e.g., D), while others are limited by both factors (e.g., AR). As was expected, these ecophysiological limitations influence both total biomass growth and its allocation. For example, during the first years after establishment, seedlings growing under higher light levels show lower height, above-ground biomass, and foliar area than under low light levels, but increased below-ground biomass and root development (Martínez Pastur et al. 2011a).

Biometric and biomass variables increased over the seasons during the studied period, except for leaves (number and foliar area), which decreased during late summer as was expected. This is a consequence of plants dropping some leaves in response to drought (Cordeiro et al. 2009). The decreased leaf area in drought-stressed plants could be viewed as a strategy to postpone drought by reducing whole-plant transpiration, with minor effects on plant water balance. However, this strategy may also reduce whole-plant net photosynthesis, and above-ground biomass allocation (Martínez Pastur et al. 2007; Cordeiro et al. 2009). Martínez Pastur et al. (2011b) determined the importance of the retention pattern on the regeneration in the harvested forests. They concluded that aggregates produce edge effects that are proportional to the distance and aspect from their edges, while dispersed retention can give protection but can also negatively influence the regeneration depending on proximity. The different microenvironments in the dispersed retention also differentially influence survival rate and regeneration growth, and it was expected that the magnitude of this impact will also be related to position (distance and aspect) from the aggregated retention.

\subsection{Implications for silvicultural management}

Under dense canopies, rapid replacement of the seedling bank has been observed in N. pumilio forests (Cuevas 2000), and mortality can be mainly related to water stress and secondarily to light availability stress (Peri et al. 2009). In the harvested areas, natural regeneration reacts quickly to the canopy opening, but establishment and performance are strongly influenced by the different microenvironments. Traditional harvesting methods homogenize the stands, leading to biodiversity depletion in managed areas (e.g., Gustafsson et al. 2012), but also reduce the resilience of the stand to climate change (e.g., ENSO regional influence) or to ecological characteristics of the species (e.g., seeding cycles, which can occur every 7-10 years) (Cuevas 2000). The alternative silvicultural proposal of variable retention maintains some of the heterogeneity of the original primary unmanaged stands (Gustafsson et al. 2012; Lindenmayer et al. 2012); e.g., in Tierra del Fuego, a greater area of edges generated in the aggregated retention ameliorates the impact of harvesting on microclimate (Martínez Pastur et al. 2011b). In fact, variable retention in $N$. pumilio forests provides a range of microenvironments which meet the habitat requirements of several taxa, allowing them to survive within the harvested areas (e.g., Lencinas et al. 2011), as well as providing a range of microenvironments for regeneration (Martínez Pastur et al. 2011b). However, the proportion of the different microenvironments in these harvested forests will determine the natural regeneration establishment, survival and growth, and consequently the success of the silvicultural management.

Silvicultural proposals and logging strategies must include actions to provide favorable microenvironment conditions for regeneration survival and growth. For example, dispersed retention increases seed production and offers shelter for regeneration during the establishment and growth during the first years after harvesting; however, it also decreases water availability beneath the crowns of the retained trees. For this reason, dense dispersed retention usually delays the normal development of the natural regeneration (Martínez Pastur et al. 2011a). This negative effect of the overstorey on regeneration was also described by Palik et al. (2003) in US forests. If the reduction in seedling density exceeds acceptable limits, one proposed solution is to decrease crown cover, tree density, or retention levels and thereby relieve some competitive pressure on plants while maintaining the biodiversity conservation objectives under desirable overstorey levels (Lencinas et al. 2011). Also, in southern Patagonia, coarse woody debris resulting from the harvesting (rotten wood, small diameter logs and branches) can represent up to $50 \%$ of the harvested volume (Martínez Pastur et al. 2011b) and is usually accumulated next to roads. This excessive debris accumulation can impede seedling establishment and their performance during the following years. To compensate for this, spreading the debris across the harvested area or moving it to the most adverse areas (e.g., north side of the aggregates) (Martínez Pastur et al. 2011b) will encourage the complete natural regeneration of the managed stands.

We provide evidence based on natural regeneration success of N. pumilio, a middle-tolerant species (Gutiérrez 1994; Martínez Pastur et al. 2007) that shows the benefits of microenvironment variations generated during harvesting. Competing benefits of different spatial distributions of retention argue for use of spatially variable overstorey retention (e.g., dispersed retention and different levels of aggregation) 
within a single harvest unit (Gustafsson et al. 2012; Lindenmayer et al. 2012). Under this approach, as with any other silvicultural system, regeneration of trees is an important measure of management success (Palik et al. 2003). Providing the full range of microenvironments in the post-harvesting stand will provide the greatest chance of achieving successful regeneration of the stand.

Acknowledgments The authors gratefully thank the Centro Austral de Investigaciones Científicas, Ricardo Vukasovic of Servicios Forestales Consultancy, Los Cerros Ranch, and Kareken sawmill for their support during the completion of this work.

Funding We acknowledge funding (2009-2011) by the MIA-CATIE project (Fondo de apoyo a proyectos de investigación en mitigación y adaptación al cambio climático en la gestión forestal sostenible).

\section{References}

Ammer C, Stimm B, Mosandl R (2008) Ontogenetic variation in the relative influence of light and belowground resources on European beech seedling growth. Tree Physiol 28:721-728

Blood LE, Titus JH (2010) Microsite effects on forest regeneration in a bottomland swamp in western New York. J Torrey Bot Soc 137:88102

Bray RH, Kurtz LT (1945) Determination of total, organic, and available forms of phosphorus in soils. Soil Sci 59:39-45

Buckley D, Crow T, Nauertz E, Schulz K (2003) Influence of skid trails and haul roads on understory plant richness and composition in managed forest landscapes in Upper Michigan, USA. For Ecol Manage 175:509-520

Caldentey J, Ibarra M, Hernández J (2001) Litter fluxes and decomposition in Nothofagus pumilio stands in the region of Magallanes, Chile. For Ecol Manage 148:145-157

Caldentey J, Mayer H, Ibarra M, Promis A (2009) The effects of a regeneration felling on photosynthetic photon flux density and regeneration growth in a Nothofagus pumilio forest. Eur J For Res 128:75-84

Chen J, Franklin JF, Spies TA (1995) Growing-season microclimate gradients from clearcut edges into old-growth Douglas-fir forests. Ecol Appl 5:74-86

Chen J, Saunders SC, Crow TR, Naiman RJ, Brosofske KD, Mroz GD, Brookshire BL, Franklin JF (1999) Microclimate in forest ecosystem and landscape ecology. Bioscience 49:288-297

Cordeiro Y, Pinheiro H, dos Santos FB, Correa S, Silva J, Dias-Filho M (2009) Physiological and morphological responses of young mahogany (Swietenia macrophylla King) plants to drought. For Ecol Manage 258:1449-1455

Cuevas JG (2000) Tree recruitment at the Nothofagus pumilio alpine timberline in Tierra del Fuego, Chile. J Ecol 88:840-855

Fitter AH, Hay RK (2002) Environmental physiology of plants. Academic, London, p 397

Frangi J, Richter L (1994) Balances hídricos de bosques de Nothofagus de Tierra del Fuego, Argentina. Rev Fac Agron de La Plata 70:6579

Frazer GW, Fournier RA, Trofymow JA, Gall RJ (2001) A comparison of digital and film fisheye photography for analysis of forest canopy structure and gap light transmission. Agric For Meteorol 109:249263

Gustafsson L, Baker S, Bauhus J, Beese W, Brodie A, Kouki J, Lindenmayer D, Lõhmus A, Martínez Pastur G, Messier C,
Neyland M, Palik B, Sverdrup-Thygeson A, Volney J, Wayne A, Franklin JF (2012) Retention forestry to maintain multifunctional forests: a world perspective. Bioscience 62:633-645

Gutiérrez E (1994) Els boscos de Nothofagus de la Terra del Foc com a paradigma de dinámica successional del no-equilibri. Treballs de la SCB 45:93-121

Heinemann K, Kitzberger T (2006) Effects of position, understorey vegetation and coarse woody debris on tree regeneration in two environmentally contrasting forests of north-western Patagonia: a manipulative approach. J Biogeogr 33:1357-1367

Heinemann K, Kitzberger T, Veblen T (2000) Influences of gap microheterogeneity on the regeneration of Nothofagus pumilio in a xeric old-growth forest of northwestern Patagonia, Argentina. Can J For Res 30:25-31

Heithecker TD, Halpern CB (2007) Edge-related gradients in microclimate in forest aggregates following structural retention harvests in western Washington. For Ecol Manage 248:163-173

Howard TM (1973) Studies in the ecology of Nothofagus cunninghamii Oerst. in natural regeneration on the Mt. Donna Buang Massif, Victoria. Aust J Bot 21:67-78

Kupferschmid AD, Bugmann H (2005) Effects of microsites, logs and ungulate browsing on Picea abies regeneration in a mountain forest. For Ecol Manage 205:251-265

Lencinas MV, Martínez Pastur G, Gallo E, Cellini JM (2011) Alternative silvicultural practices with variable retention to improve understory plant diversity conservation in southern Patagonian forests. For Ecol Manage 262:1236-1250

Lindenmayer D, Franklin JF, Lõhmus A, Baker S, Bauhus J, Beese W, Brodie A, Kiehl B, Kouki J, Martínez Pastur G, Messier C, Neyland M, Palik B, Sverdrup-Thygeson A, Volney J, Wayne A, Gustafsson L (2012) A major shift to the retention approach for forestry can help resolve some global forest sustainability issues. Conserv Let 5:421431

Martínez Pastur G, Peri P, Vukasovic R, Vaccaro S, Piriz Carrillo V (1997) Site index equation for Nothofagus pumilio Patagonian forest. Phyton 6:55-60

Martínez Pastur G, Lencinas MV, Peri P, Arena M (2007) Photosynthetic plasticity of Nothofagus pumilio seedlings to light intensity and soil moisture. For Ecol Manage 243:274-282

Martínez Pastur G, Peri P, Cellini JM, Lencinas MV, Barrera M, Ivancich H (2011a) Canopy structure analysis for estimating forest regeneration dynamics and growth in Nothofagus pumilio forests. Ann For Sci 68:587-594

Martínez Pastur G, Cellini JM, Lencinas MV, Barrera M, Peri P (2011b) Environmental variables influencing regeneration of Nothofagus pumilio in a system with combined aggregated and dispersed retention. For Ecol Manage 261:178-186

Martínez Pastur G, Jordán C, Lencinas MV, Soler Esteban R, Ivancich H, Kreps G (2012) Landscape and microenvironmental conditions influence over regeneration dynamics in oldgrowth Nothofagus betuloides Southern Patagonian forests. Plant Biosyst 146:201-213

McCarthy J (2001) Gap dynamics of forest trees: a review with particular attention to boreal forests. Environ Rev 9:1-59

Modry M, Hubeny D (2003) Impact of skidder and high-lead system logging on forest soils and advanced regeneration. J For Sci 49:273280

Neyland M, Hickey J, Read SM (2012) A synthesis of outcomes from the Warra silvicultural systems trial, Tasmania, Australia: safety, timber production, economics, biodiversity, silviculture and social acceptability. Aust For 75:147-162

Palik B, Mitchell RJ, Pecot S, Battaglia M, Pu M (2003) Spatial distribution of overstorey retention influences resources and growth of longleaf pine seedlings. Ecol Appl 13:674-686

Peri P, Martínez Pastur G, Lencinas MV (2009) Photosynthetic and stomatal conductance responses to different light intensities and 
water status of two main Nothofagus species of south Patagonian forest. For Sci 55:101-111

Rosenfeld JM, Navarro Cerrillo RM, Guzmán Alvarez JR (2006) Regeneration of Nothofagus pumilio (Poepp. et Endl.) Krasser forests after five years of seed tree cutting. J Environ Manage 78: $44-51$

Schmidt MG, Ogden AE, Lertzman KP (1998) Seasonal comparison of soil temperature and moisture in pits and mounds under vine maple gaps and conifer canopy in a coastal western hemlock forest. Can J Soil Sci 78:291-300
Soler Esteban R, Martínez Pastur G, Lencinas MV, Borrelli L (2012) Forage differential use between native and domestic herbivores in southern Patagonian Nothofagus forests. Agrofor Syst 85:397-409

ter Braak CJF, Šmilauer P (2002) CANOCO reference manual and CanoDraw for Windows. User's guide: software for canonical community ordination. Version 4.5. Microcomputer Power, Ithaca, New York, USA

Wardle JA (1970) The ecology of Nothofagus solandri: 3. Regeneration. N Z J Bot 8:571-608 